\title{
PROCEEDINGS OF THE ELEVENTH SUMMER MEETING, HELD AT COLUMBUS, OHIO, AUGUST 22, 1899
}

\author{
Herman Le Roy Fairchind, Secretary
}

CONTEN'TS

Segsion of Tuesday, August $10 \ldots \ldots$ Page

Election of Fellows.

Glacial phenomena of central Ohio [abstract]. by Frank $\ldots \ldots \ldots \ldots \ldots$

Random, a pre-Cambrian Upper AJgonkian terrane; by C. D. Walcott. . 3

The section at Schoharie, New York [abstract]; by John J. Stevenson. . b

Geological results of the Indiana Coal Survey; by George H. Ashley.... 8

Triassic coal and coke of Sonora, Mexico; by E. T. Dumble......... 10

Register of the Columbus meeting, $1899 \ldots \ldots \ldots \ldots \ldots \ldots \ldots \ldots \ldots \ldots . \ldots$

\section{Session of Tursday, A ugust 10}

The Society was called to order at 10.15 o'clock a $\mathrm{m}$, in the geological lecture-room, Orton Hall, Ohio State University. The President, Professor Benjamin K. Emerson, occupied the chair throughout the meeting. By mutual understanding between the Society and the American Association for the Advancement of Science, the Geological Section (Section E) of the Association had temporarily suspended its sessions and yielded the use of its room and time to this meeting of the Society.

\section{ELECTION OF FELLOWS}

The Secretary announced that the four candidates for fellowship had received a nearly unanimous vote of the ballots transmitted, and that they were elected, as follows:

\section{Fellows Elected}

Clevfland Abze, JR., A. B., A. M., Ph. D., Westminster, Maryland. Professor of Geology, Western Maryland College.

A1,Fred Hulse Brooks, B. S., Washington, D. C. Assistant Geologist, United States Geological Survey.

William Libbey, A. M., Sc. D., Princeton, New Jersey. Professor of Physical Gengraphy, Princeton University, and Director E. M. Museum of Geology.

George Burbank Shatruck, B. S., Ph. D., Baltimore, Maryland. Associate in Physiographic Geology, Johns Hopkins. University. 
Upon motion of J. J. Stevenson, it was voted to make H. L. Fairchild a life member, "in consideration of his long and valuable services to the Society as Secretary."

The reading of papers was declared in order. The first paper of the program was

\section{THE GEOLOGY OF COLUMBUS AND VICINITY}

BY EDWARD ORTON

Remarks were made by the President and Frank Leverett.

The second paper was entitled:

GLACIAL PHENOMENA OF CENTRAL OHIO

BY FRANK LEVERETT

[Abstract]

A general description was given of glacial and interglacial formations represented in central Ohio as follows: First, the Illinoian drift; second, a soil and weathered zone (Sangamon) formed on the surface of the Illinoian drift; third, a silt deposit, probably of Iowan age, which caps the weathered surface of the Illinoian drift; fourth, the Wisconsin drift, with its several moraines. The lobation of the ice-sheet in the Scioto basin and the axiradient movement shown by strix received attention. The principal changes of drainage which have been produced by glaciation were also discussed. The paper was accompanied by a map.

In the discussion of the paper Professor W. G. Tight argued that the smooth till plains of the region might conceal very irregular surface, and that the ice-flow was not controlled by topography. Remarks were also made by the President, I. C. White, G. F. Wright, and the author.

The following paper was read by title, in the absence of the author:

GLACIAL AND MODIFIED DRIFT IN MINNEAPOLIS, MINNESOTA

BY WARREN UPHAM

The last paper of the morning session was entitled :

LATERAL EROSION AT THE MOUTH OF THE NIAGARA GORGE

BY G. FREDERICK WRIGHT

The substance of this paper is published in the Popular Science Monthly, volume lv, pages 145-154, June, 1899. 
Following the presentation of this paper the Society adjourned, at 12.35 o'clock, for the noon recess.

At 1.45 o'clock $p \mathrm{~m}$ the Society reconvened, and the three following papers were read by title:

\section{GEOLOGY OF OAHU, HA WAIIAN ISLANDS}

BY C. H. HITCHCOCK

The paper is printed in full in this volume.

RANDOM, A PRE-CAMBRIAN UPPER ALGONKIAN TERRANE

BY CHARIES D. WALCO'T

In a paper presented to this Society at its last meeting I gave a description of the dvalon series of Newfoundland. ${ }^{*}$ Therein it was stated that the Signal Hill sandstone and conglomerate caps the series, the Cambrian resting unconformably on the basal terrane of the Avalon series and overlapping on the Archean. No transition beds were known between the Signal Hill terrane and the Cambrian. Subsequently Mr G. F. Matthew pablished an article entitled "A Paleozoic Terrane beneath the Cambrian," $\dagger$ in which he referred the greater portion of the red and green shales, with their interbedded limestones, on Smith sound and Trinity bay, Newfoundland, to a pre-Cambrian terrane. These shales and limestones were correlated with similar beds on Hanford brook, New Brunswick, to which he had given the name "Etcheminian."

In June, 1899, accompanied by Mr S. Ward Loper to assist in collecting fossils, I visited Smith sound, and at Smith point found the Olenellus fauna 369 feet below the summit of the Etcheminian, and one of its types, Coleoloides typicalis, in the basal bed of the Cambrian, on the south side of Random island. This retains the Etcheminian of Newfoundland in the Tower Cambrian, to which the strata representing it on Manuels river were referred by me in 1888. On a second visit to the Smith Sound section later in the month, Mr J. P. Howley accompanied us, and for seventeen days we worked on the Cambrian and pre-Cambrian formations about Trinity and Conception bays. The Lower Cambrian rocks of the Smith Point section are concealed at a point $44 \mathrm{~L}$ feet beneath a thick bed of limestone, characterized by the presence of a great number of Hyolithes of various species and by Olenellus and Agraulos in its upper portion. This limestone is 369 feet beneath the conglomerate bed, which Mr Matthew places at the base of the Cambrian zone.t East of the interval covered by soil occurs a section 107 feet thick that evidently belongs to an older series, although it retains the same dip and strike as the reddish purple and green shales of the Lower Cambrian. The section exposed is as follows, downward:

* Bull. Geol. Soc. Am., vol. 10, pp. 218-220.

† Annals N. Y. Acad. Sci, vol. xii, 1899, pp. 41-56.

† Ann. Rept. New York Acad. Sci., vol, xii, 1899, p. 46, and section fig. 3, p. 48. 
a. Sandy shales, with some bands of arenaceo-argillaceous shales; a thin layer of interformational conglomerate occurs 33 feet from the bottom, and at 17 feet from the bottom are some calcareous layers and nodules...

b. Light gray quartaitic sandstone in three principal layers, 22, 24, and 20 inches thick, respectively..

c. Arenaceous shales, with thin layel's of dirty gray sandstone; well marked annelid trails occur on some of the beds of sandstone and shale...

Several hundred feet of the section along the shore are here concealed by drift, but to the eastward indurated gray sandstones and shales show in the cliffs where they are broken and distorted by dikes of basalt.

At the slate quarries east of Tilton head, on Smith sound, the basal beds of the Cambrian-green and reddish purple shales, here cleaved into slates-rest on a series of gray sandstones and shales, the dip and strike being the same, but with a thin bed of conglomerate at the base of the Cambrian. The pre-Cambrian rocks are considerably faulted and folded, but they are not the Signal Hill sandstones or conglomerates.

We next crossed to the south side of Smith sound and found the section partly concealed. Passing around Random island to Hickmans harbor, on Random sound, a section was found east of the harbor showing the Signal Hill sandstone and conglomerate, and, resting conformably on it, a series of sandstones, quartzitic sandstone, and sandy shales extending up to the base of the Cambrian. The Cambrian section extends up to the Hyolithes limestone of the Smith Point section. For the terrane between the Signal Hill and the Cambrian Mr Howley and I agreed upon the name Random.

At Hickmans Harbor point the Signal Hill conglomerate strikes north 40 degrees east; dip, 68 degrees east. At the summit of the Random terrane the strike is north 50 degrees east; dip, 70 degrees southeast. The section, as measured by $\mathrm{Mr}$ Howley, is as follows, downward:

Cambrian.

RANDOM :

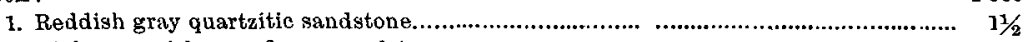

2. Light greenish gray flaggy sandstones...............................................................

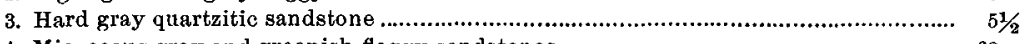

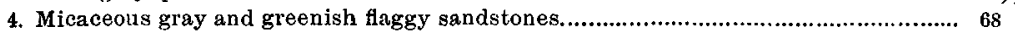

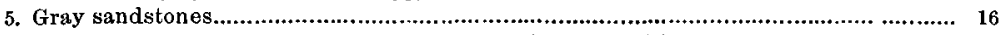

6. Greenish and bluish gray slaty arengceous beds, breaking up into fine shales in

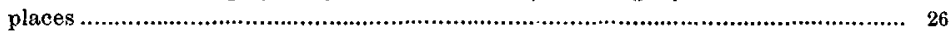

7. Pale pinkish quartzite in layers 1 to 3 feet.................................................... 25

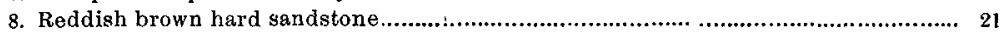

9. Massive bedded white quartzite....................................................................... 10

10. Massive and thin bedded hard gray sandstones and shales..................................... 90

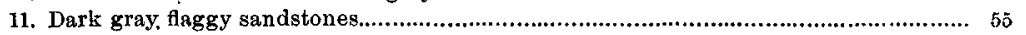

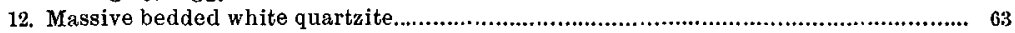

13. Massive bedded reddish gray quartzitic sandstone.............................................. 31

Signal Hile conglomerate.

In number 4 of this section I found several varieties of annelid trails, including a variety about 5 millimeters broad, a slender form $\frac{1}{2}$ millimeter broad, and an annulated trail 2 to 3 millimeters in width.

There is a fold in the Random rocks of the section forming a sharp syncline and anticline, and $I$ believe that a portion of the upper part of the Random ter- 
rane is faulted out of sight. On the opposite or eastern side of the synclinal basin holding the Cambrian rocks the Random terrane appears to be much thicker, although folded and repeated several times. On the east side of Trinity bay, at Hearts Delight harbor, I measured the following section of the Random terrane without reaching down to the white quartzite which is above the Signal Hill conglomerate:

Cambrias ; basal conglomerate.

RANDOM TRRAANE:

Feet

1. Fine silicious conglomerate, passing down iu to thick bedded gray and greenish gray

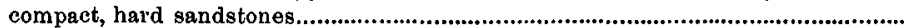

2. Silicious and sandy shales, flaggy sandstones with thick layers of sandstone in the upper 65 feet; traces of annelid trails occur on the surface of the shaly beds.........

3. Massive bedded dark gray quartzitic sandstones with a few bands of shaly sandstone; strike at base, north 50 degrees east ; dip, 75 degrees southwest.................... 700

CONOEALED By DRIFT.

The Random terrane is probably 1,000 feet, and possibly more, in thickness. It fills in a portion, if not all, of the gap between the Signal Hill conglomerate and the Cambrian. The erosion preceding the deposition of the Cambrian about Trinity bay appears to have been slight, as the conglomerate resting on the Random is rarely over 18 inches in thickness, and usually much less. This, however, is not a safe deduction, as great erosion may leave but slight trace, either in conglomerates or in apparent nonconformity in the dip or strike of the strata.

The Random terrane is considered to be the upper member of the Avalon series.* Animal life existed during the deposition of a portion of it, as is evidenced by clearly marked annelid trails. A collection of the form known as Aspidella terranovica was made from the Momable terrare of the Avalon series. It proved the supposed fossil to be a spherulitic concretion, and this removes it from among the possible pre-Cambrian forms of life.

\section{PRE-CAMBRIAN PETROGRAPHIC PROVINCE OF THE FOX RIVER VALLEY, WISCONSIN}

BY WM. H. HOBBS AND C. K. LEITH

WITH ANALYBIS BY W. W. DANIELLS

The next paper was presented by the author, as follows:

AGE AND DEVELOPMENT OF THE CINCINNATI ANTICLINE

BY AUG. F. FOERSTE

Remarks were made by H. S. Williams and J. M. Clarke.

In the absence of the author, the following paper was read by title :

LOWER DEVONIAN ASPECT OF THE LOWER HELDERBERG AND ORISKANY FORMATIONS

BY CHALLES SCHUCHRRT

This paper is printed in full in this volume. 
The next paper was entitled :

SILURIAN-DEVONIAN BOUNDARY IN NORTH AMERICA

BY HENRY S. WILLIAMS

The paper was presented only by abstract, and was discussed by J. M. Clarke and J. F. Whiteaves (a former Fellow of the Society).

The following paper was then read:

THE SECTION AT SCHOHARIE, NEW YORK

BY JOHN J. STEVENSON.

[Abstract]

The village of Schoharie, 35 miles southwest from Albany, is very near the mouth of Schoharie valley, an indentaiion of the Helderberg mountains. The section in the hills, bounding the valley at that place, extends from the Hudson to the Hamilton, and is so well exposed in detail as to afford means for comparison with sections obtained in southern Pennsylvania, as well as in Virginia, within the Appalachian region.

No trace of either Oneida or Medina appears at Schoharie, and the thin eastern representative of the Clinton resta on the Hudson. In this respect the condition differs from that in the Shawangunk mountains - the southeasterly border of the Catskill area-where the Oneida is a massive conglomerate. The contrast with the southern sections is striking. In those the Hudson passes very gradually into the red or lower Medina, as is seen well in southern Pennsylvania and still better in southwestern Virginia. Rhyncotrema capax, Rafinesquina alternata, Plectambonites sericea, Ambonychia radiata, A vicula emacerata, and some other forms continue into the red Medina, even to within 100 feet of the white. Medina in the more southern localities.

The Niagara is represented at Schoharie by the Coralline limestone, about 6 feet thick, containing great numbers of Favosites niagarensis, Stromatopora concentrica, and a few mollusks. This dark brown limestone is succeeded by the Waterlime, in all about 40 feet thick, whose lowest portion, about 6 feet thick, is the well-known "Cement rock" of Schoharie and Ulster counties. This rock is of lighter color and very different composition. In a great part of the Appalachian region the Salina shales, often several hundred feet thick, are seen between these rocks, but in the Schoharie area the limestones are in contact and the change in conditions was so slight that the Favosites and other forms continued into the Waterlime, the coral occurring so abundantly in some places as to render the "Cement rock" worthless. "The higher part of the Waterlime is flaggy and much of it thinly laminated, while the rock becomes more calcareous.

The passage to Helderberg is marked physically by a complete change in color, the Waterlime being light gray and the Tentaculite, the lowest division of the Helderberg, very dark blue; yet Spirifera vanuxemi and Leperditia alta, two forms characterizing the Tentaculite throughout, occur in the thicker beds of the Waterlime.

The successive divisions of the Helderberg, Tentaculite, Lower Pentamerus, Del- 
thyris, Scutella, and Upper Pentamerus--45, 65, 95, 8, and 22 feet thick respectivelyare very distinct, the color, texture, and composition of the limestones in the several divisions being characteristic. As a whole, the fauna of each division is its own, but some forms pass from the lower Pentamerus to the top, while each division contains a greater or less number of forms found in that below, showing that despite the sharp physical boundaries, there were by no means equally abrupt changes affecting animal life. Indeed, those forms which existed throughout show no differences in shape, size, or markings, such as would enable one to determine the horizon whence they came. This appears to have been the constant condition throughout the Appalachian region as far as Virginia, for the divisions are characteristic of the section.

The contact between Helderberg and Oriskany was not observed anywhere in the neighborhood of Schoharie, but at two points the concealed interval is not more than 18 inches. Apparently the change from one to the other is as abrupt as is possible. The Upper Pentamerus becomes somewhat flaggy in the upper portion, but the rock is a rather pure limestone, crinoidal and containing many cyathophylloid corals. The Oriskany, however, is a hard sandstone, slightly calcareous and very ferruginous. It is thin at Schoharie, barely 10 feet, and is seldom seen in place, its ferruginous matter causing somewhat rapid decay. The change in composition marks a physical change which sufficed to cause an almost complete change in fauna. Only Leptæna rhombridalis and Eatonia singularis appear to have passed upward from the Helderberg. The former is excessively rare, while the latter is equally rare in the Helderberg.

Here, again, one finds a striking contrast with the southern sections. Not only is the Oriskany much thicker at the south, but there is also a transition from the Helderberg as gradual as that from the Niagara to the Waterlime at Schoharie. In sonthern Pennsylvania the transition bed is a silicious limestone, well shown at Hyndman, in Bedford county, and containing Favosites helderbergiæ, along with characteristic Oriskany forms. In Maryland the Oriskany yields fine crinoids, and crinoidal stems are common in Virginia. These are unknown in the Schoharie region. Still further south the upper beds of the Helderberg became sandy, and the admixture of Helderberg forms in the Iower Oriskany is such that the writer during his first study of the region referred the beds to the Helderberg.

The most notable differences between the sections are the gradual transition between Ordovician and Silurian and between Silurian and Devonian at the south and the equally gradual passage from Niagara to Waterlime at the north.

Remarks upon Professor Stevenson's paper were made by J. M. Clarke, H. S. Williams, I. C. White, and A. F. Foerste.

The next paper was read by title :

THE OZARKIAN AND ITS SIGNIFICANCE IN THEORETIC GEOLOGY

BY JOSEPH LE CONTE

This paper is printed in the Journal of Geology, volume vii, pages $525-544$. 
The following paper was entitled:

GEOLOGICAL RESULTS OF THE INDIANA COAL SURVEY

BY GEORGE H. ASHLEY

Contents

Page

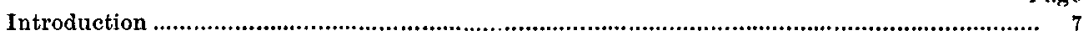

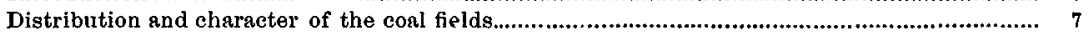

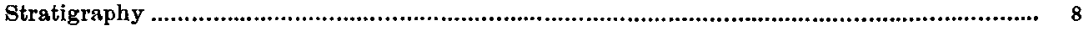

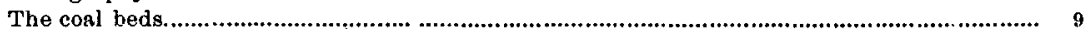

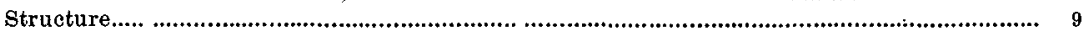

\section{- In'TRODUCTION}

Under the supervision of $\mathrm{Mr}$ W. S. Blatchley, State Geologist of Indiana, the coal survey of the state was started in August, 1896, and completed early in 1899. Associated with the writer in the fieldwork were Messrs C. E. Siebenthal, E. M. Kindle, J. A. Price, J. T. Scovell, and Thomas Watson.

\section{Distribution and Character of the Coal Fieliss}

Geographically the Coal Measures of Indiana are part of the eastern-central, or Illinois, basin, and are found in the southwestern part of the state. A line enclosing the field would include about 9,000 square miles; but actually the Coal Measures cover only between 6,000 and 6,500 square miles, of which about onehalf is underlain by workable coal.

The surface features of the coal field are largely of the flat type, common to the glacial area of the northern central states. Exposures of the country rock are rare over most of the area, and exploration is mainly by the drill. The southeastern part of the field is outside of the glacial area and ranges from very rugged along. the eastern edge, where the heavy basal sandstone outcrops, to flat or rolling over most of the area to the west where shale outcrops predominate.

\section{STRATIGRAPHY}

The relations of the Coal Measures to the Iower or Eo-carboniferous are those of nonconformability. An uplift seems to have taken place toward the close of the Lower Carboniferous period, most noticeable to the north, which, throngh failure of original deposition or by subsequent erosion, or both, resulted in the absence of the uppermost beds of the Lower Carboniferous in that direction, and left an irregular surface, upon which the Coal Measures were laid down.

The first appearance of coal-forming conditions resulted in the laying down of one or two unimportant beds, which to the north are generally absent or, when found, appear to be confined to the hollows in the Lower Carboniferous surface. Then came the deposition of a massive sandstone along the entire eastern edge of the present coal field. This sandstone, which is occasionally gritty, is the equivalent of the Pottsville conglomerate series of Pennsylvania. It appears to have been a shore deposit, not underlying the main body of the Coal Measures, or subsequently removed, from the fact that many drillings a short distance west of its outcrop report only shale at its horizon. Between this basal sandstone and the main body of the Coal Measures is another noticeable nonconformity, as before, more marked to the north. In this case the non-coal-forming conditions persisted 
to the north, while several hundred feet of strata and many coal beds were being laid down in the southern and south western part of the field before the coal-forming conditions had reached the present northern limits of the coal area. This slow overlapping from the southwest toward the east and north was one of the most interesting discoveries made by the survey. At the extreme north coal vr is found resting unconformably on the basal sandstone, while at the south this coal outcrops 20 or 30 miles west of the sandstone, from which it is separated by over a dozen coal beds and their intervening strata.

It would be out of place here to go into the detailed history of the laying down of the main measures, though a large number of interesting features were worked out. Nonconformities occur at numerous places in the series of events, usually with erosion levels with a difference of less than 20 feet. In one case, however, the streams eroded their channels to depths of up to nearly 200 feet, cutting out the coals and other strata. These channels are abundant over the north part of the field, and are well exposed in Parke, Fountain, and Vermillion counties, due to the extensive quarrying of the sandstone with which they are filled. These channels may correspond to a nonconformity found further south between coals via and vib, or to one existing between the Coal Measures and the massive Merom sandstone which overlies them.

Due to the overlap described, the thickness of the Indiana Coal Measures is variable, ranging from abont 1,000 feet in the southwest to only a few hundred feet at the north.

\section{The Coal Beds}

In number, as high as 17 beds have been found in a single drilling, with a total thickness of over 32 feet. At least 20 coal horizons outcrop, and, counting the overlapped beds that do not outcrop, it is possible many other horizons exist. Exact information about the lower outcropping coal beds might increase the number given, as the persistence of the lower beds is assumed and not real.

In extent the coal horizons vary greatly. Some of the upper horizons are thought to have been traced the whole length of the coal field. Thus what we have called coal vir would appear to have been a practically continuous bed from the Ohio river to where its outcrop crosses the Illinois line, in Vermillion county. In the same way we have traced the horizon of coal vi continuously, though the coal is not continuous. To the south it runs out, to the north it becomes pockety, but between are two basins of several hundred or a thousand square miles each, where the coal is thick, persistent, and extremely regular in its details, clay or pyrite bands from a fraction of an inch to two inches thick persisting over the whole of the basins; so of many of the other of the upper coals, and also the accompanying beds, especially the limestones.

Going down to the horizons of coals II, Irr, and rv, the coals are found to occur in small basins, often of only a few acres, the coal running from 3 to 5 feet thick in the center of the basin and often running down to as many inches or nothing over the elevated divides between the basins. Yet even in such cases it is often possible to trace partings and other minor stratigraphic details of the coal from one basin to another over areas of several hundred square miles. The basin structure in most of these cases would seem to be due to the irregularities made by the erosion of the subcoal surfaces. These coals tend to be " block coals," having a remarkably perfect system of joint planes, besides usually being non-caking.

In thickness the coals range up to 10 feet. Several of the upper beds will main- 
tain a nearly uniform thickness of from 4 to 6 feet or more over areas of several hundred square miles. The lower beds, while often reaching from 4 to 6 feet in the center of small basins, will average much below 3 feet on account of their thinness over the intervening ridges.

\section{STRUCTURE}

The major structure of the field is that of a monocline, the dip being to the south of west in the northern part and north of west in the southern part, being noticeably affected by the thickening of the strata to the south. The dip is slight, averaging about 24 feet to the mile, though running as high as 100 feet to the mile.

In its minor structure the field presents a great variety of interesting featuresfaults of many types, veins of clay, sandstone and coal, and local irregularities and disturbances of many kinds. Attention has already been called to some of these in the Proceedings of this Society and of the Indiana Academy of Science.

Remarks upon Doctor Ashley's paper were made by J. A. Holmes, I. C. White, J. M. Clarke, the President, and the author.

The next paper was entitled:

CAPE FEAR SECTION IN THE COASTAL PLAIN

BY J. A. HOLMES

Remarks were made by E. T. Dumble.

The next paper was read by title as follows :

OCCURRENCES OF CORUNDUM

BY J. H. PRATT

The last paper of the meeting was presented informally by the author, entitled :

TRIASSIC COAL AND COKE OF SONORA, MEXICO

BY E. T. DUMBLE

The Santa Clara coal field of Sonora, Mexico, is situated in the Yaqui river drainage, 95 miles northeast of Ortiz, near the mining town of La Barranca.

The region is mountainous. Although the elevations in this particular area are not very great, there are mountains on the north and east. Aguja, on the west, has a height of 3,950 feet, while the Carrizo, which is still higher, is on its northern border. Candelero, another large mountain, the top of which is about 3,700 feet above sealevel, lies between Aguja and the coal field. While there are numerous peaks and high points scattered over the coal field, that portion of the area east of Candeléro is much lower than that west and is partly rolling, partly hilly. Candeléro trail, which may be called the western border of the developed field, is over 1,800 feet in height, and Tarahumari, near its center, 1,170 feet, while La Barranca in the west is 2,000 or over. From Tarahumari enst the slope is considerable also, the point where the Calera empties into the Yaqui being about 700 feet above tide.

The three principal creeks are the Arellanas on the north, Calera in the center, and La Barranca in the southwest. The Arellanas and La Barranca are true 
canyons-long, narrow, tortuous, steep-sided, and with many falls. Both are fed by numerous springs and carry watet in holes the year round. The Arellanas is much the larger of the two.

Unlike these creeks, the Calera occupies a large drainage basin, and, with its numerous tributaries, it carries off the water of several square miles. Most of its branches head on the flanks of Candelero or in the ridges which are the continuation of that mountain to the north and south. Ontside of a few springs of very moderate flow, Culera and its branches are dry, except during the rainy season.

Calera basin is the coal field proper, and was named from one of the principal affluents of the Calera, the Santa Clara, where the coal was first discovered and worked.

The rocks of the coal region are Triassic sands, clays, and igneons deposits, with a few later intrusives. A short distance south these are seen to rest upon syenites, referred by the Mexican geologists to the Archean, and on the north we have, near Los Bronces, similar syenites, and a series of interbedded quartzites and granular limestones provisionally referred to the Cambrian.

The only literature to which I have had access treating on the general geology of this region is the report by Señors Jose G. Aguilera and Ezequiel Ordoñez.* To the facts there stated $I$ added the results of my own observations in a paper entitled "Notes on the Geology of Senora, Mexico." $\dagger$ Based on these, the Triassic here is separated into two divisions:

The Barranca, or clastic sediments ; the Lista Blanca, or igneous rocks.

The Barranca division is composed of four members. The basal is a series of sandstones and sandy slates; the second a series of interbedded shales, slates, and sands, with occasionally a band of limestone near the top and with beds of graphite and coal. This is succeeded by a massive sandstone or quartzite carrying pyrites, which often segregate in patches and show strong colorings of iron or copper. The upper bed is a conglomerate or breccia of sandstone with a silicious matrix. This is almost always so strongly altered as to be of the nature of a quartzite, and is seemingly unconformable with the other beds.

The Lista Blanca division is a volcanic complex, consisting of a series of andesitic lavas, agglomerates, volcanic conglomerates, and tuffs, with some rhyolites toward the top. These are found resting directly upon the rocks of the Barranca division, and further north they underlie the Cretaceous deposits.

The Triassic rocks of the Santa Clara coal field belong to the second series of the Barranca division and to the Lista Blanca. The beds have a general strike north east-southwest, and an average dip of 30 degrees southeast. The field is separated into two parts by a band of the overlaying Lista Blanca, which obscures the connection of the coal beds in the two areas.

The heavier sands are usually somewhat uniform and persistent, but at times they show considerable variability. They comprise conglomerates, grits, and medium grained sands, their massiveness depending largely on the size of the grain. They are usually gray in color, but may change to brown within a few feet. In hardness they range from friable sandstone to quartzite, but the former condition is rare. They are somew hat clayey at times, and when these clayey sandstones are metamorphosed, as they often are, it is hard to tell which is metamorphic rock and which is igneous. Occasionally the imprint of a branch or trunk of a tree is

\footnotetext{
* Contained in Bóletin del Instituto Geológico de México, nums. 4, 5, y 6. Bosquejo geológico de México.

† Trans. American Institute of Mining Engineers.
} 
seen in them and, more rarely, a fragment of silicified wood. The slätes, shales, and finer sands which make up the other beds are extremely variable, and their characters have been very well described by Aguilera.* This variability makes it extremely difficnlt to trace the beds with certainty, since a clay slate may pass into a sandy slate or bedded sand, or a sandy slate into a coarse massive sandstone in a comparatively short distance.

The slates are extremely rich in plant remains, which are well preserved, and many of them very beautiful. So far as I know, they have only been studied slightly as yet. Señor Aguilera gives a list of those noted by Doctor Newberry and a few others determined later, and I sent a small collection to Dr I. C. White, which was given to Professor Wm. M. Fontaine, who writes me as follows:

\footnotetext{
“The plants that Professor White sent some time ago as coming from you and obtained in Mexico certainly come from a horizon well up in the Mesozoic. Most if not all of them seem to be new species. That and their small number make it not possible to give with certuinty the exact horizon. To judge, however, from them, it appears to be the uppermost Trias or Rhetic. They impress me as being of about the age of Newberry's Abiqua copper mine plants, or those of the older Mesozoic of Virginia and North Carolina."
}

In addition to these plants in the shale and thin bedded slates, the more massive slates carry silicified stems and branches of shrubs, and the finer grained bedded sands trunks of trees up to more than a foot in diameter. In grain these latter resemble the elm.

None of the beds show cross-bedding to any extent.

Each prominent bed of slate and shale seems to have one or more seams of coal in it, and, although like Triassic coals in general, the deposits may be more or less lenticular, nearly all of these beds are workable somewhere along their extent in this territory.

The limestones are only occasionally present and generally near the top of the division. They are usually very argillaceous, but sometimes more calcareous.

Only a few localities have yielded fossils other than plant remains. Previous to this exanination the only marine fossils known were those from San Marcial, 60 miles west of this locality, described by Meek in volume 1 of the Paleontology of California. So far I have not found here the forms described by him, but in a band of limestone I find, as imprints, a great number of other forms of marine invertebrates which have not yet been studied.

The only member of the Lista Blanca present in this immediate field is the heavy agglomerate, the basal conglomerate not appearing unless it is represented by the ferruginous quartzitic breccia placed in the Barranca division. It presents no features different from those already described. $\dagger$ It lies with apparent unconformity on the Barranca, but is involved with that division in its various flxeures.

The two sections given represent the general relations of the beds in each of the two areas with what seems to us the probable connection. If this be correct, they represent fully the variability of the beds in longitudinal extent as described by Señor Aguilera.

The regularity of these beds is much disturbed by intrusions of igneous rocks. This rock, which is principally trachyte, has been forced along the bedding planes of the slate or between the slate and coal for long distances. In places it may be only a foot or two in thickness, and on weathered faces so closely resemble a bed

* Op. cit.

† Trans. American Institute of Mining Engineers. 
of sandy slate that its presence would be unsuspected until it thickens suddenly into a laccolite of 20,30 , or more feet, throwing the overlying beds entirely out of their regular course. The greater part of the flexures of the area are due to such laccolites.

The largest one of these laccolites is an intrusion of diorite just west of Tarahumari. It has a length from north to south of nearly half a mile and its breadth is but little less. Its thickness is more than 100 feet. It lies between the Tarahumari sand and the underlying slate, and in places has been forced between the slates as well, until it now appears to be interbedded with them.

Some of the exposures of trachytic rocks look very much like sandstones, and the resemblance is heightened by the pebbles of flint (?) and of graphite, which they often carry in considerable numbers.

While the intrusive rock probably passes from one bed of slate to another, only one or two such breaks have been observed here. It is on account of this interbedded condition that the coal beds of this area are workable, and to it is largely due the presence of workable beds of coke.

While some of the coal has a bituminous structure, analyses show that it is all anthracite. It breaks with square, even fracture, has splendent luster, black powder, and is not as hard as Pennsylvania anthracite. It contains from 4 to 8 per cent moisture and about the same percentage of ash. The volatile hydrocarbons are under 5 . per cent, and the fixed carbon ranges from 76 to 85 per cent. Such tests as have been made in burning it have shown very good results; specific gravity, 1.70 to 1.75 .

The coke is dark gray to grayish black in color, metallic to submetallic luster, breaks with even fracture, and shows columnar structure like oven coke. Powder black; pores smaller and coke denser than most oven coke. In places it appears lamellar, as if pressure had flattened the walls of the pores. It is a good fuel in blacksmith forge, open fire, or assay furnace, burning steadily without deflagration, and will probably be entirely satisfactory for all metallurgical uses, except such as may require a greater porosity.

The coke is simply a local condition of the coal, largely due to the presence of the igneous rock in immediate proximity of the bed.

In two of the principal openings on the coke the igneous rock practically forms the roof, and in a third instance it forms the floor of the seam. In these openings there are occasional inclusions of the igneous rock in the coke, and there are other places where it thickens and cuts the coke ont almost entirely. The plastic nature of the igneous rock at the time of its intrusion is shown by the way in which the coke is mixed through it in these horses, if they may be so called, and also by the presence in the same intrusive rock, in other exposures, of fragments of graphite, which represent the passage of the plastic material along or through some coal bed.

In other beds, however, coke appears without any igneous rock near it, so far as we can find. In one seam of anthracite, which has a thickness of 4 feet, we find pockets of coke near the center, and in one coke bed we find pockets of anthracite near the base. In two or three beds we find both coke and anthracite present, but in different benches. In one case there is a clay parting 3 inches thick between the coke and underlying anthracite, but in the others no parting is found, and in one the anthracite is on top and coke below.

In one coke bed there is some tendency to concentric structure, and kidneys or eggs of coke are scattered through the more massive material.

In the vicinity of San Xavier and Los Bronces, north and east of here, some 
work has been done on seams of coal of Triassic age. One mine which I visited showed a bed of 8 feet of good coal with a narrow slate parting. Another had 10 feet of coal, much of which was of concentric structure, shelling out into "eggs" of greater or less hardness.

To the east of San Marcial, which is 35 miles northeast of Ortiz, some work has been done on supposed coal beds. After cleaning out some of the old works I found the beds to have a very black, bright appearance, looking like a fine face of anthracite. All efforts, however, to burn the supposed coal were fruitless. When put in the fire it would on becoming hot deflagrate violently, scat tering burning sparks, which were simply very fine scales of the red-hot material, for several feet. On falling they would quickly become black again, and it was rare that we could get a fragment to show any ash at all. Whatever value it may have in other ways, as a fuel it was a flat failure. If, on further examination, this should prove worthy of a name among minerals, I would suggest the name of " garciaite," from the owner of the concession on which I first examined it. Later I found the same material in beds of the same age in the Whetstone mountains of A rizona.

The only coal found in my work around San Marcial was in the vicinity of El Salto. The only bed I saw there was fair coal, but thin. It burned all right, although the ash was considerably heavier than that in the Santa Clara coals.

'The President declared the meeting adjourned.

\section{Register of the Columbus Mefiting, 1899}

The following Fellows attended the sessions of the Society :
G. H. AsHLEY.
Frank Lueveretr.
J. M. Clarke.
Eijward Ortion.
E. 'T. Dumble.
C. S. Prosser.
B. K. Emerson.
F. W. Simonds.
H. L. FatrChILD.
J. J. Stevenson.
G. P. Grimsley.
F. B. TAYLOR.
Arthur Hollick.
W. G. 'Tigh'.
J. A. Holmes.
I. C. WhITE.
C. R. Keyres.
H. S. Williams.

G. F. Wright.

Present at the meeting of the Society, 19.

The following Fellows arrived too late for the session of the Society, but were in attendance upon the sessions of Section E, American Association for the Advancement of Science:
E. R. Barbour.
A. M. MiLLER.
H. C. Hovey.
W J McGes.

Total attendance, 23. 